\title{
Rare Reason for Vaginal Bleeding and Dysmenorrhea in A Young Woman: Endometriosis in A Cervical Polyp
}

\section{Genç Bir Kadında Vajinal Kanama ve Dismenorenin Nadir Bir Sebebi: Servikal Polipte Endometriozis}

\author{
(1) Deniz Şimşek ${ }^{1}$, (1) Ali Akdemir ${ }^{2}$, (1) Gülruh Emiroğlu Büberal ${ }^{3}$, (1) Özgür Deniz Turan ${ }^{4}$, (1) Ahmet Mete Ergenoğlu² \\ ${ }^{1}$ Bursa Yüksek Intisas Research and Training Hospital, Clinic of Obstetrics and Gynecology, Bursa, Turkey \\ ${ }^{2}$ Ege University Faculty of Medicine, Department of Obstetrics and Gynecology, İzmir, Turkey \\ ${ }^{3}$ Ege University Faculty of Medicine, Department of Pathology, Izmir, Turkey \\ ${ }^{4}$ Aydın Adnan Menderes Faculty of Medicine, Department of Obstetrics and Gynecology, Aydın, Turkey
}

Keywords

Cervical polyp, endometriosis, vaginoscopy

Anahtar Kelimeler

Servikal polip, endometriozis, vajinoskopi

Received/Geliş Tarihi : 22.11.2016

Accepted/Kabul Tarihi : 10.05 .2017

doi:10.4274/meandros.galenos.2017.08208

Address for Correspondence/Yazışma Adresi: Deniz Şimşek MD,

Bursa Yüksek Iintisas Research and Training

Hospital, Clinic of Obstetrics and Gynecology,

Bursa, Turkey

Phone : +90 2323901700

E-mail :drdenizsimsek@hotmail.com

ORCID ID: orcid.org/0000-0002-0975-9457

(C) Meandros Medical and Dental Journal, Published by Galenos Publishing House.

This is article distributed under the terms of the

Creative Commons Attribution NonCommercial 4.0

International Licence (CC BY-NC 4.0).

\begin{abstract}
Abnormal vaginal bleeding in adolescent and young women is not a rare event and can be attributed mainly to anovulatory cycles, pregnancy-related bleeding, and endocrinological disorders in this age group. Cervical polyps commonly occur during the reproductive years, especially after the age of 40 . Here we present a rare reason for vaginal bleeding and dysmenorrhea in a 20-year-old woman caused by endometriosis in a cervical polyp. Twenty-year-old patient admitted to Ege University Faculty of Medicine Gynecologic clinic due to vaginal bleeding and prolapsed lesion which was seen from introitus of the vagina. She had mental retardation and seizures since infancy. Her first menstrual bleeding occurred at the age of 14 and she had regular menstrual cycles. Gynecologic speculoscopy and bimanual examination could not be performed because the patient was sexually inactive and she did not accept the bimanual vaginal examination. Magnetic resonance imaging was performed. Multiple cervical polyps and genitourinary system malformation were reported. Vaginoscopy with hysteroscope was performed and cervical polyp in $5 \mathrm{~cm}$ length was detected. Polypectomy was performed with operative hysteroscope without complication. No damage was occurred to hymen. Pathologic result was determined endometriosis in cervical polyp. Cervical polyp in young women is rare and endometriosis in cervical polyp is detected only in a few cases in literature. It is a reason of abnormal vaginal bleeding and dysmenorrhea. Vaginal masses that prolapse from the cervix should be examined precisely. Malignancies of the cervix, vagina and uterus should be kept in mind in patients with malformations and anomalies. We aimed to present this rare case and to show the feasibility of vaginoscopy with operative hysteroscope in sexually inactive patients. Pre-operative evaluations should be patient specific and care should be taken to avoid complications.
\end{abstract}

Öz

Adölesanlarda ve genç kadınlarda anormal vajinal kanama nadir olmayan bir durumdur. Bu yaş grubunda en sık sebepler anovulatuvar sikluslar, gebelikle ilişkili kanamalar ve endokrinolojik bozukluklardır. Servikal polipler genellikle reprodüktif çağda, özellikle 40 yaş sonrasında saptanmaktadır. Yirmi yaşındaki bir kadında 
saptanan vajinal kanamanın ve dismenorenin nadir bir sebebi olan servikal polipte endometrizis olgusunun sunumu amaçlanmıştır. Yirmi yaşında hasta, Ege Üniversitesi Tıp Fakültesi, Jinekoloji Kliniği'ne vajinal kanama ve vajen introitusundan gözlenebilen sarkmış bir lezyon yakınması ile başvurdu. Hastanın doğumda başlayan mental retardasyon ve epilepsisi mevcuttu. İlk menstruasyon kanaması 14 yaşında gerçekleşmiş ve düzenli sikluslara sahipti. Hastaya spekulum ve jinekolojik bimanuel muayene hastanın cinsel inaktif olması ve vajinal muayeneyi kabul etmemesi nedeniyle yapılamadı. Hasta manyetik rezonans görüntüleme ile değerlendirildi ve multipl servikal polipler ve genitoüriner sistem malformasyonu saptandı. Histeroskop ile vajinoskopi gerçekleştirildi ve $5 \mathrm{~cm}$ uzunluğunda servikal polip saptandı. Operatif histeroskop kullanılarak polipektomi gerçekleştirildi. Komplikasyon ve himende yaralanma gerçekleşmedi. Patolojik inceleme sonucu servikal polipte endometriozis olarak raporlandı. Genç kadınlarda servikal polip nadir olmakla beraber servikal polipte endometriozis literatürde sadece birkaç olgu sunumunda belirtilmiştir. Anormal vajinal kanama ve dismenoreye sebep olur. Serviksten prolabe olan vajinal lezyonlar dikkatlice incelenmelidir. Malformasyon ve anomalisi olan hastalarda serviks, vajina ve uterusun maligniteleri akılda tutulmalıdır. Bu nadir olguyu sunmak ve seksüel olarak inaktif kadınlarda operatif histeroskop kullanılarak vaginoskopinin uygulanılabilirliğinin değerlendirilmesi amaçlanmıştır. Pre-operatif değerlendirme her hastaya özgü olmalı ve komplikasyonlardan kaçınmak için dikkatli olunmalıdır.

\section{Introduction}

Abnormal uterine bleeding is a common disorder which refers the disturbance of the normal menstrual bleeding range. In adolescent patients, there are several reasons; including anovulatory cycles which are related to immaturity of the hypothalamicpituitary-ovarian axis, pregnancy related bleeding, thyroid dysfunction, hypothalamic dysfunction, bleeding disorders and hormonal contraception (1). Cervical polyps are the benign growths of the cervix which commonly occur especially after the age of 40 (2). The etiology is unknown. It may cause abnormal vaginal bleeding as post-coital or intermenstrual bleeding. Endometriosis is the existence of the endometrial gland and the stroma outside of the uterine cavity. It is a benign, estrogen dependent, inflammatory disease with an incidence of 5-15\% in reproductive age (3). The lesions are commonly located in the ovaries, peritoneum, uterosacral ligament, cul-de-sac, bladder and bowel (4). Cervix is the rare location of the endometriosis which is usually detected in microscopic evaluation with an incidence of $0.2 \%(5)$.

We aimed to represent a case of cervical polypoid endometriosis because it is only detected in a few patients in the literature. She was the youngest in the literature and treated with operative hysteroscope without any complication. Written informed consent was obtained from the patient for publishing the individual medical records.

\section{Case Report}

Twenty-year-old patient admitted to gynecology clinic with active vaginal bleeding for 20 days and prolapsed lesion seen from the introitus of the vagina. Patient has mental retardation and seizures since infancy. Parents of the patient specified that she had vaginal bleeding or spotting for 20 days and sudden episodes of shouting during menstruation period. Recognizing the bloody lesion from the vaginal introitus caused them admit to the hospital. Patient was sexually inactive thus speculum examination and bimanual gynecologic examination were unable to be performed. Vaginal introitus was seen by opening labium majora, minora widely and bloody polypoid lesion that lied through the proximal part of the vagina. Her menstruation started at age of 14 and no hormonal medicine usage was detected in the history. Her mother did not use diethylstilbestrol during her pregnancy. Pelvic magnetic resonance imaging relieved that the patient had pelvic kidney, uterus bicornis and multiple polypoid lesions within the vagina related with the anterior lip of the cervix and reached till the introitus of the vagina (Figure 1). Informed consent was obtained and vaginoscopy

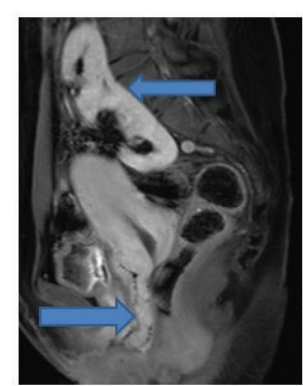

A

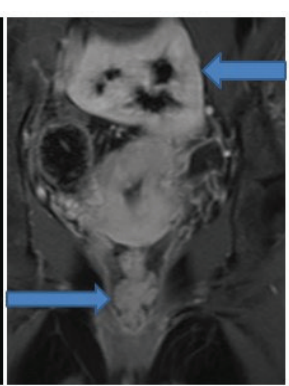

B

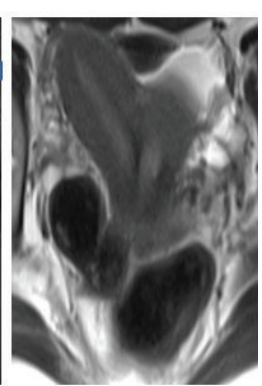

C
Figure 1. A) View of the cervical polyp (inferior arrow) and pelvic kidney (superior arrow). B) View of the cervical polyp (inferior arrow) and pelvic kidney (superior arrow) in coronal section. C) View of the uterus bicornis 
evaluation was planned. Five $\mathrm{mm}$ hysteroscope was used and revealed that cervical polyp in $5 \mathrm{~cm}$ length which was originated from the anterior lip of the cervix. Vagina was filled by glycine and polypectomy was performed with operative hysteroscopy which was $9 \mathrm{~mm}$ in diameter by using monopolar electrosurgical device. Lesion was in $5 \mathrm{~cm} \times 3 \mathrm{~cm} \times 1 \mathrm{~cm}$ in size, cystic nature and contained brownish/blackish areas (Figure 2). No complication and bleeding was occurred and hymen was determined intact and undamaged (Figure 2). Pathologic evaluation reported that cervical polyp including endometriotic areas with CD10 positive and Ki67 expression was reported as $10 \%$ in immunohistochemical evaluation (Figure 3-6).

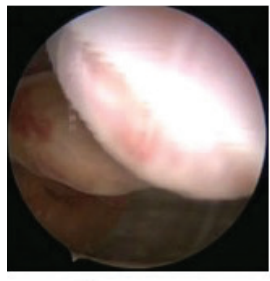

A

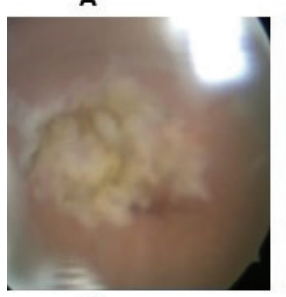

D

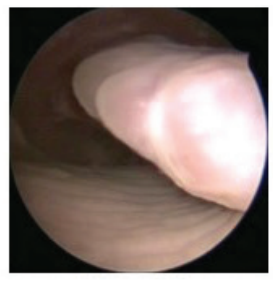

B

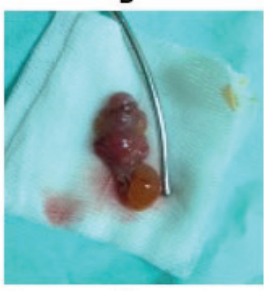

E

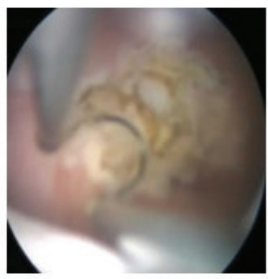

C

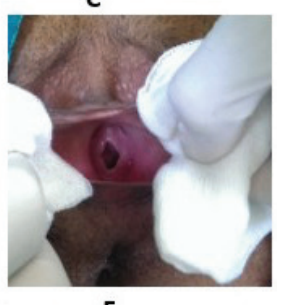

$\mathbf{F}$
Figure 2. A, B) View of the cervix and cervical polyp in vaginoscopy. C, D) post-operative view of the cervix after excision of the polyp. E) macroscopic view of the cervical polyp. F) post-operative view of the hymen

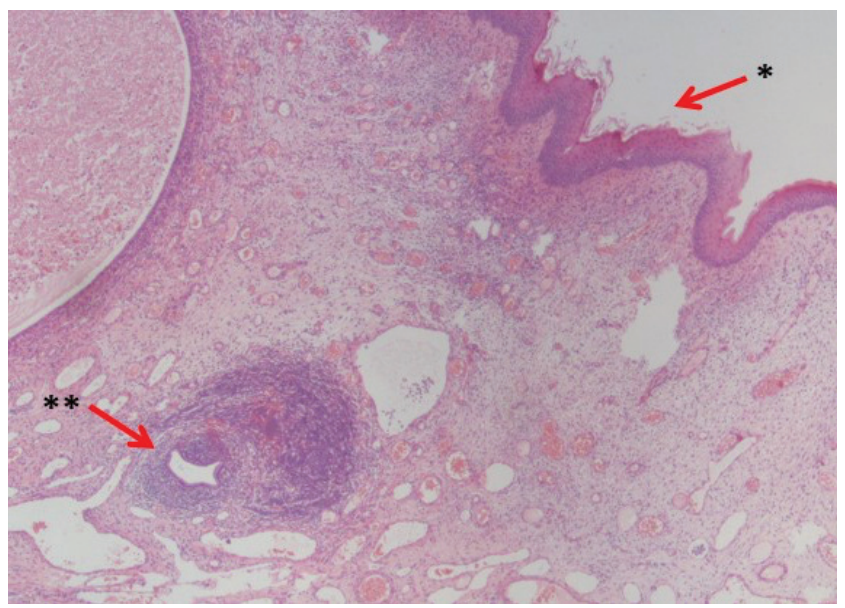

Figure 3. *: Cervical polyp epithelial. **: View of the endometrial stroma and gland in cervical polyp

\section{Discussion}

Endocervical polyps are benign and common disease in gynecology. Although etiology is not clear, microscopic clues are thought to be an inflammatory process because of the squamous metaplasia, dilated cervical glands with chronic inflammation cells (2). It may cause vaginal discharge and bleeding owing to the ulceration of the epithelium and secretion from the glands (6). The hallmark of our case is the age of the patient and being sexually inactive. Patient had no property to have chronic inflammatory exposure thus metaplasia or genetic basis could play a role in etiology. She had Mullerian Anomaly and pelvic kidney.

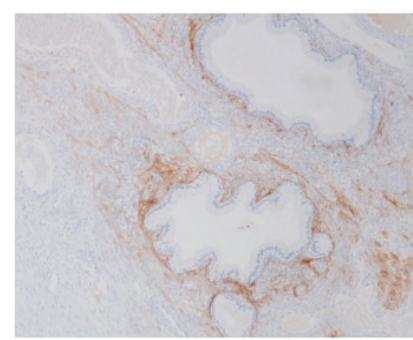

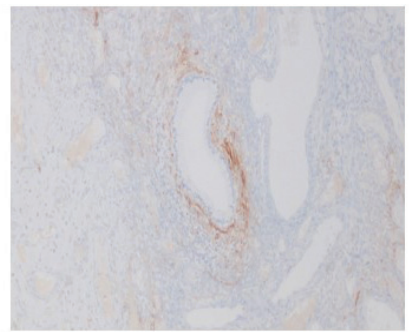

B

Figure 4. Endometriosis focus in polyp

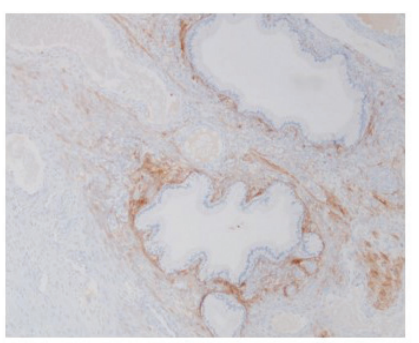

A

Figure 6. CD 10 positive endometrial stroma with immunohistochemical staining

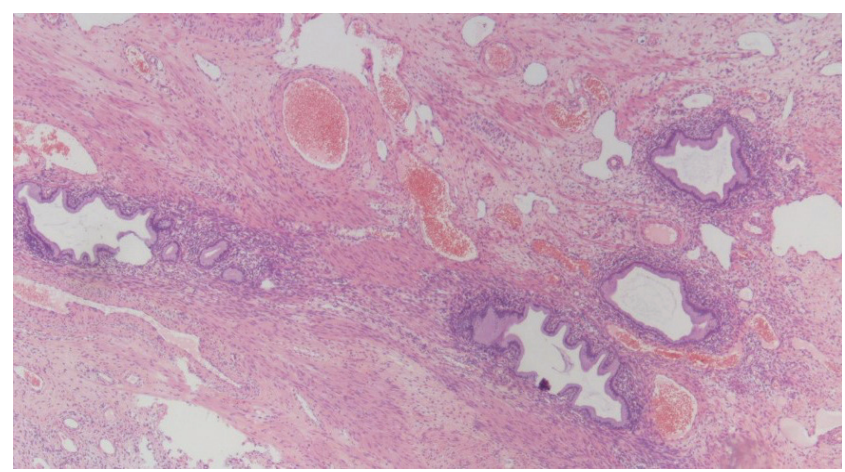

Figure 5. Endometrial stroma and glands in polyp 
This genetic basis and metaplasia theory can also explain the existence of the endometriosis in cervical polyp. In 1927 Sampson (7) suggested the retrograde menstruation theory to explain the peritoneal and ovarian endometriosis. This is also acceptable as endometrial cells during menstruation can immigrate to cervical polyp in our case to clarify endometriosis existence in cervical polyp. The other theories which are cholemic metaplasia and induction theory which defends hormonal, biological and genetic factors can differentiate the cells to endometrial cells and generate endometriosis (8).

Cervical endometriosis is rare and usually detected retrospectively with pathologic evaluation after excision operations like conization, loop electrosurgical excision procedure or hysterectomy (5). Endometriosis in cervical polyp has reported in only a few case reports in the literature. We have reviewed only six reports in literature. Our patient is the youngest comparing all case reports and only one of these six patients is sexually inactive like our patient (9-14). Endometriosis in cervical polyp causes the symptoms of endometriosis and polyp like; vaginal discharge, vaginal bleeding or spotting, dysmenorrhea, dyspareunia and post-coital bleeding. Diagnosis is easy for polyp which is speculum examination yet pathologic evaluation is obligatory for endometriosis. Huge protruding masses can mimic cervical, endometrial or vaginal malignancies. We could not perform speculum examination because of the virginity of the patient. Abnormal vaginal bleeding should be analyzed precisely. In children and adolescent patients, trauma or child abuse should be primarily excluded. Pregnancy and anovulatory cycles are the most common reasons of the abnormal vaginal bleeding. Ultrasonography or MRI can be performed to visualize cervical polyps. We performed MRI to understand the origin, borders or invasion of the lesion to have an opinion about malignancies. After MRI report revealed multiple lesions we also queried diethylstilbestrol exposure whether these lesions were associated with vaginal adenosis although diethylstilbestrol was withdrawn in early 1980's.

Vaginoscopy with hysteroscope is minimal invasive procedure which provides adequate and perfect view of the vagina. Hysteroscope which is in $5 \mathrm{~mm}$ or $9 \mathrm{~mm}$ diameter, appeared to be safe and feasible for sexually inactive patients. Vaginoscopy and hysteroscopy are not only diagnostic but also therapeutic tools for gynecology. It is the fact that informed consent should be taken and possibilities of the complications should be explained. Experienced surgeons and meticulous approach will definitely decrease the complications.

In conclusion; abnormal vaginal bleeding should be examined precisely. Cervical polyp and endometriosis in polyp should be kept in mind in patients with lesions protruding from introitus or filling vagina even in young patients. Excision procedure is obligatory for especially symptomatic patients to exclude any malignancies and treatment can be performed with hysteroscope.

\section{Ethics}

Informed Consent: An informed consent was obtained from all patients.

Peer-review: Externally peer-reviewed.

\section{Authorship Contributions}

Concept: A.A., Design: A.M.E., Data Collection or Processing: A.A., Analysis or Interpretation: Ö.D.T., Literature Search: D.Ş., Materials: G.E.B., Writing: D.Ş.

Conflict of Interest: No conflict of interest was declared by the authors.

Financial Disclosure: The authors declared that this study received no financial support.

\section{References}

1. ACOG Committee Opinion No. 651:Menstruation in Girls and Adolescents: Using the Menstrual Cycle as a Vital Sign. Obstet Gynecol 2015: 126: e143-6.

2. Wright TC, Ronnett BM, Ferenczy $A$. Benign diseases of the cervix. In: Kurman RJ, Hedrick Ellenson L, Ronnett BM, editors. Blaustein's pathology of the female genital tract. New York: Springer, 2011: 155-91.

3. Gao X, Yeh Y-C, Outley J, Simon J, Botteman M, Spalding J. Healthrelated quality of life burden of women with endometriosis: a literature review. Curr Med Res Opin 2006; 22: 1787-97.

4. Jenkins S, Olive DL, Haney AF. Endometriosis: pathogenetic implications of the anatomic distribution. Obstet Gynecol 1986; 67: 335-8.

5. Wang S, Li XC, Lang JH. Cervical endometriosis: clinical character and management experience in a 27-year span. Am J Obstet Gynecol 2011; 205: 452. e1-452.e5.

6. Bucella D, Frédéric B, Noël J-C. Giant cervical polyp: a case report and review of a rare entity. Arch Gynecol Obstet 2008; 278: 2958.

7. Sampson JA. Peritoneal endometriosis due to the menstrual dissemination of endometrial tissue into the peritoneal cavity. Am J Obstet Gynecol 1927; 14: 422-69. 
8. Vinatier D, Orazi $G$, Cosson $M$, Dufour P. Theories of endometriosis. Eur J Obstet Gynecol Reprod Biol 2001; 96: 2134.

9. Othman NH, Othman MS, Ismail AN, Mohammad NZ, Ismail Z. Multiple Polypoid Endometriosis-A Rare Complication Following Withdrawal of Gonadotrophin Releasing Hormone (GnRH) Agonist for Severe Endometriosis: A Case Report. Aust N Z J Obstet Gynaecol 1996; 36: 216-8.

10. Fukunaga M. Uterus-like mass in the uterine cervix: superficial cervical endometriosis with florid smooth muscle metaplasia? Virchows Archiv 2001; 438: 302-5.
11. Kano H, Kanda H. Cervical endometriosis presented as a polypoid mass of portio cervix uteri. J Obstet Gynaecol 2003; 23: 84.

12. Félix A, Nogales FF, Arias-Stella J. Polypoid endometriosis of the uterine cervix with Arias-Stella reaction in a patient taking phytoestrogens. Int J Gynecol Pathol 2010; 29: 185-8.

13. Kwek JW, H'ng MWC, Chew SH, Tay EH. Florid polypoid endometriosis of the cervix with left ureteric obstruction: a mimic of cervical malignancy. Ultrasound in Obstet Gynecol 2010; 36: 252-4.

14. Jaiman S, Gundabattula SR, Pochiraju M, Sangireddy JR. Polypoid endometriosis of the cervix: a case report and review of the literature. Arch Gynecol Obstet 2014; 289: 915-20. 